\title{
3. Some observations on the EPSU case: a bad judgment for democracy and subsidiarity, alias a textbook example of not promoting the European Social Dialogue
}

\author{
Filip Dorssemont ${ }^{1}$
}

Future generations will judge harshly those who allow the historic achievement of an EU social dialogue to wither and die. ${ }^{2}$

\section{INTRODUCTION}

In a famous speech of 14 January 1985 addressing the European Parliament, Jacques Delors, then President-elect of the European Commission, stated:

Democracy is not just Europe's credibility in everyday life: it also means vitality in industrial relations and maximum participation. Justice means more than a fair reward for initiative and risk-taking: it also means the kind of community that makes all its members welcome and is mindful of the need to provide equal opportunities for all. So democracy and justice. Let me then ask this: when will we see the first European collective bargaining agreement? I would insist on this point. A European collective agreement is not just an empty slogan. It would provide a dynamic framework, one that respected differing views - a spur to initiative, not a source of paralyzing uniformity. ${ }^{3}$

\footnotetext{
1 The author has not represented any of the parties of this case in court. He has taken an interest in the subject matter on the occasion of a previous 'case' which did not go to court (the hairdressers' agreement). Although the author was consulted by the applicants in the procedure as an independent academic, this chapter is written in his own name without prior discussion with any of the applicants concerned. The opinions expressed in this chapter are solely those of the author of these pages, just as the opinions he gave to the applicants were.

2 Brian Bercusson, European Labour Law (CUP 2009) 636. (PR query to AU not yet addressed)

3 The thrust of Commission policy, Bulletin of the European Communities Supplement 1/85, 9 .
} 
Hence, in the mind of Jacques Delors there was no opposition between the development of the Social Dialogue and democracy. The development of the Social Dialogue would enhance the participation of citizens, and hence the credibility of Europe. In their seminal book Le Moment Delors, Didry and Mias argued that the involvement of social partners was the winning formula for the development of a Social Europe, highlighting the role of Delors as an architect of this approach. ${ }^{4}$ To some extent, the involvement of social partners was a way to overcome a regulatory deadlock; it deblocked legislative paralysis and enhanced legitimacy. ${ }^{5}$ Attempts to undermine the European Social Dialogue, or even the mere lack of political will to promote it, constitute a direct threat to democracy.

In this contribution, I will endeavour to provide a mildly critical analysis of the EPSU judgment of the General Court of 24 October 2019.6 This judgment constitutes a major setback in the history of the European Social Dialogue insofar as it demonstrates that two major EU institutions (the Commission and the Court of Justice) have failed to 'recognise and promote the role of the social partners at its [the Union's] level', as prescribed in Article 152 TFEU. The EPSU agreement, its genesis and the history of its non-implementation will be analysed in section 2 . As will be argued in section 3, such history generates a feeling of déjà $v u$. This was not the first time that the Commission refused to implement an agreement following a joint request by the signatory parties to do so. However, it is the first time that this attitude was attacked before the General Court. Following an analysis of the procedure and the judgment in section 4, a series of critical observations concerning its implications will be presented in sections 5 to 8 and a final conclusion will be furnished in section 9 .

\footnotetext{
$4 \quad$ Claude Didry and Arnaud Mias, Le moment Delors (Peter Lang 2005) 349.

5 See especially Antonio Lo Faro, Regulating Social Europe. Reality \& Myth of Collective Bargaining in the EC Legal Order (Hart Publishing 2000) 192. The following quote of the monography is nearly prophetic: 'One cannot help wondering (even though the hypothesis seems somewhat remote) what the consequences would be, if quite apart from possibly deeming an agreement to be contrary to Community law, the Commission gave a negative assessment of the substantive choices made by the social partners', ibid, 115.

6 Case T-310/18 EPSU and Willem Goudriaan v Commission (EPSU) ECLI:EU: $\mathrm{T}: 2019: 757$.
} 


\section{THE EPSU AGREEMENT: A HISTORY OF INDUCED BARGAINING}

The EPSU agreement is the outcome of a round of bargaining induced by the European Commission. Lo Faro has distinguished this process from voluntary bargaining on the basis of the origin triggering the bargaining process. ${ }^{7}$ The genesis of the bargaining procedure was heteronomous ${ }^{8}$ and the signatory parties have asked the Commission to start a heteronomous avenue of implementation. ${ }^{9}$ Thus, the Commission already considered the matter in a Staff Working Document of 26 July 2013, enshrining the conclusions of a so-called fitness check on the issue of the information and consultation of workers regulated by Directives 98/59, 2001/23 and 2002/14:

More specifically, the exclusion of smaller enterprises and public administration from the scope of application of the Directives has been questioned on the grounds of the Directives' lack of practical relevance for a significant share of the workforce. Another gap was analysed in the separate exercise involving the exclusion of seafarers from the scope of application of a number of EU labour law Directives including the three I\&C Directives. ${ }^{10}$

On 10 April 2015 the European Commission initiated a formal consultation procedure on the basis of Article 154(2) TFEU on the issue, inter alia, of the extension of the scope ratione personae of these directives to civil servants and employees in public administration of the Member States. ${ }^{11}$ On 21 December 2015, EUPAE (European Public Administration Employers) and TUNED (Trade Unions' National and European Administration Delegation) concluded a Framework Agreement on the information and consultation of civil servants and employees of central government administrations. On 1 February 2016 they filed a joint request to implement the agreement, which was addressed to the European Commission. It took the European Commission more than two years to respond to this request. On 5 March 2018 the European Commission

7 Lo Faro (n 5) 53-89.

8 The word heteronomous is being used in opposition to autonomous. A process of bargaining can be called heteronomous if it is triggered by an external pressure, hence 'induced'. The implementation of an agreement is heteronomous when it depends upon an external intervention by public institutions as opposed to social partners.

9 European Commission, Consultation document: First phase consultation of Social Partners under Article 154 TFEU on a consolidation of the EU Directive on information and consultation of workers, C(2015) 2303 final.

10 European Commission, Commission Staff Working Document, 'Fitness check' on EU law in the area of Information and Consultation of Workers, SWD(2013) 293 final, 5 .

11 C(2015) 2303 final (n 9). 
formally refused the request, indicating it would not submit a proposal to the Council to implement the agreement by means of a directive for three reasons enumerated in a tiny paragraph, and recapitulated in the judgment of the General Court. ${ }^{12}$

First, the Commission stated that central government administrations were under the authority of the Member States' governments, that they exercised the powers of a public authority and that their structure, organisation and functioning were entirely the responsibility of the Member States. This statement is, arguably, extremely problematic. First and foremost, it is in the nature of the information and consultation procedure that managerial prerogatives are not affected. Second, the suggestion that EU labour law would in no way affect the powers of a public authority or its structure, organisation and functioning is simply untrue. Here and now, EU free movement rules affect recruitment and promotion policies, ${ }^{13}$ preventing these administrations from committing acts of discrimination based upon sex, race, religion or belief, handicap and sexual orientation. ${ }^{14}$ Multiple EU rules related to health and safety apply to governmental administration as well. ${ }^{15}$

The Commission's second claim was that provisions ensuring a certain degree of information and consultation of civil servants and employees of those administrations already existed in many Member States. Although this may well be the case, it is immaterial. Until the Maastricht Treaty, EU labour law was solely based upon a model of approximation of labour laws of Member States which directly affect the establishment or functioning of the internal market. In sum, the mere fact that provisions exist was not considered an obstacle to, but a condition of, legislative intervention.

Finally, the Commission observed that the significance of those administrations depended on the degree of centralisation or decentralisation of the Member States, so that, in the event of the implementation of the Agreement by a Council decision, the level of protection of civil servants and employees of public administrations would vary considerably across Member States. This argument is not convincing either. It is contrary to a major finding of the fitness test: ${ }^{16}$ that the cost of non-intervention was in fact unequal treat-

12 See EPSU (n 6) paras 5-6.

13 See e.g.. Article 45 TFEU enshrining the principle of free movement of workers does apply to the majority of the workers in central government administration, with the exception of those workers in the public service sensu stricto.

14 For Example the EU Directives 2000/78 (General Framework), 2000/43 (Race and Ethnic Origin) and 2006/54 (Equal Treatment Men and Women).

15 EU Directive 2003/88/EC (Working Time) and EU Directive 89/391/EEC (Health and Safety).

$16 \operatorname{SWD}(2013) 293$ final (n 10). 
ment and that intervention would reduce the existing extent of that unequal treatment. As will be highlighted infra, on a proposal of the Commission, the European Council explicitly invoked equality as a reason to intervene in order to overcome another exclusion of a category of workers from the directives dealing with worker involvement. ${ }^{17}$

\section{A BAD OMEN: A COMPARISON WITH THE 'HAIRDRESSERS' AGREEMENT}

The attitude of the European Commission might give rise to a feeling of déjà $v u$. The European Commission's refusal mirrors a previous refusal of a sectoral agreement on the issue of hairdressers' health and safety. ${ }^{18}$ On 26 April 2012, Coiffure EU and UNI Europe Hair \& Beauty concluded an Agreement on Health and Safety. ${ }^{19}$ Despite a joint request by the signatory partners, the European Commission made it abundantly clear that it would not propose to the Council that this be implemented by means of a directive. ${ }^{20}$ In casu, the agreement had not formally been induced. It had a voluntary origin. In view of this refusal, the social partners renegotiated the agreement in order to facilitate the implementation. This negotiation was not carried out under the shadow of the law, ${ }^{21}$ but under the darker shadow of a 'grumpy' European Commission reluctant to propose implementation. It subsequently refused to implement this renegotiated agreement concluded on 23 June 2016.

17 See Recital 4 Directive (EU) 2015/1794 of the European Parliament and of the Council of 6 October 2015 amending Directives 2008/94/EC, 2009/38/EC and 2002/14/EC of the European Parliament and of the Council, and Council Directives 98/59/EC and 2001/23/EC [2015] OJ L263/1, as regards seafarers. This directive relates to worker involvement in relation to collective redundancies, transfer of undertaking, information and consultation at the level of the establishment or undertaking and at community level.

18 See Filip Dorssemont, Klaus Loercher and Melanie Schmitt, 'On the Duty to Implement European Framework Agreements: Lessons to be Learned from the Hairdressers Case' (2019) 48(4) Industrial Law Journal 571.

19 European Framework Agreement on the protection of occupational health and safety in the hairdressing sector, at www.uni-europa.org/wp-content/uploads/2016/06/ EFA_OHS_HairdressingSector_signed_20160623.pdf, accessed 19 June 2021.

${ }^{20}$ European Commission, $\bar{C}$ Communication Regulatory Fitness and Performance (REFIT): Results and Next Steps, COM(2013) 685 final.

21 A negotiation is carried out 'under the shadow of the law' when it is induced as a result of an initiative of the Commission envisaging a proposal for a Directive in the field of Social Policy in the meaning of Article 154(2) TFEU. The notion of 'bargaining in the shadow of the law' was introduced and used in this context by Brian Bercusson, European Labour Law (Butterworths 1996) 541. 
This refusal of the Commission (implicit or explicit) to implement the agreement was unprecedented in the history of the European Social Dialogue. Although it was never refuted that the Commission could and should operate a legality check, many scholars have argued that the Commission did not have the right to refuse to submit a proposal to implement on purely political reasons, unrelated to a legality check. On the basis of previous European Commission communications, the following issues can be considered to be part of the legality check: the assessment of representativeness, the question whether the object of the agreement falls within the ambit of EU competences and is in conformity with EU law, and last but not least the issue of whether the agreement will or will not hamper the development of small and medium enterprises. ${ }^{22}$

Comparison of these two cases makes it clear that the Commission, on the one side, has made better efforts to formally motivate its refusal. In the 'Hairdressers' case, it is in fact very difficult to identify any formal definitive decision. The refusal has a more implicit nature. In the case of the Agreement on Information and Consultation in Central Governmental Administrations (CGA Agreeement), the refusal is formal. In the first case the European Commission, in its informal approach to the agreement, used ridiculous arguments related to appropriateness. Thus, Juncker alleged that the Commission should not legislate 'on high heels', although the agreement is mute on the issue of shoes. The nature of the arguments used by the Commission in the case of the CGA Agreement appears more technical, albeit also ill-founded. Due to the agreement's technical nature, the arguments could be qualified as partially related to a legality check. They seem to support the idea that insofar as the Commission is not competent to intervene, it would be ultra vires to implement an agreement. However, the argument that no intervention was necessary in view of the apparently satisfactory acquis at the level of the Member States can in my view only relate to appropriateness.

In sum, whereas the 'hairdressers' agreement amounted to a refusal based upon issues of appropriateness, the CGA Agreement was rejected on the basis

22 See European Commission, Communication concerning the application of the Agreement on social policy presented by the Commisison to the Council and to the European Parliament COM (93) 600 final; European Commission, Commission communication concerning the development of the social dialogue at Community level COM (96) 448 final; European Commission, Communication from the Commission adapting and promoting the social dialogue at Community level COM(98) 322 final; and European Commission, Communication from the Commission - The European social dialogue, a force for innovation and change, Proposal for a Council Decision establishing a Tripartite Social Summit for Growth and Employment COM(2002) 341 final. 
of arguments presented as legal arguments, which are badly motivated and are at odds with the fact that the Commission consulted the social partners to come up with solutions.

\section{TAKING ARTICLE 155 TFEU AND CIVIL SOCIETY SERIOUSLY}

On 15 May 2018 the European Federation of Public Service Unions (EPSU) and its Secretary General, Mr Willem Goudriaan, brought an application for annulment of the contested decision. ${ }^{23}$ This section takes a bird's-eye view of the procedure and the judgment. The employer's side did not join the application. EPSU was not the signatory party of the agreement, but was a cofounder of the signatory trade union TUNED. The application was considered to be admissible.

The Commission's refusal was not seen as a preparatory act, but as a definitive position. ${ }^{24}$ It had the effect of closing a preliminary procedure laid down in view of certain persons (id est: the social partners) and of not opening the procedure for the adoption of a substantive act. Hence, it produced legal effects. The Commission did not dispute that EPSU had legal standing. The Court accepted that EPSU did have legal standing, since although addressed to TUNED, the latter lacked corporate personality and autonomy. ${ }^{25}$ Hence, the result of the Social Dialogue in which TUNED participated had to be approved by the decision-making bodies of the two co-founders, EPSU and CESI. Given that the application was admissible for EPSU, the objection against the standing of its Secretary General became irrelevant. ${ }^{26}$

The claimants challenged the decision on two distinct grounds. First was that Article 155(2) TFEU does not provide a right to the European Commission to refuse to submit a proposal following the joint request. ${ }^{27}$ In other words, the claimants argued that the European Commission was under an obligation to grant a joint request to submit a proposal of a directive implementing the agreement, except in the case of insufficient representativeness of the social partners or if the clauses of the agreement were contrary to EU law. The second line of the claimants' arguments relates to the motivations of the decision, which were considered to rely on insufficient reasons. ${ }^{28}$ This calls

\footnotetext{
EPSU (n 6) para 7.

Ibid, para 28.

Ibid, para 39.

Ibid, paras 39-40.

Ibid, para 45.

28 Ibid, paras $120-41$.
} 
for a doctrinal analysis of the interpretation of Article 155(2) TFEU, which is furnished in the following paragraphs.

\subsection{The Judgment of the General Court}

In assessing the scope of Article 155(2), the General Court (GC) tried to sort the arguments raised by the applicants into three categories. It distinguished arguments relevant for the literal interpretation, for the contextual interpretation and for the teleological interpretation from so-called other arguments. ${ }^{29}$ If looked at closely, these 'other arguments' do relate to provisions of the Treaties which, in my view, could have been integrated into a contextual and teleological analysis as well. By excluding these arguments from the contextual and teleological interpretation, the GC has severely undermined the legal strategy of the applicants and impoverished, to a significant degree, the contextual and teleological analysis concerned. This dissociation has not enhanced the credibility of the GC in dealing with this case.

The GC ruled that a mere literal or lexical interpretation of Article 155(2) takes into account the literal meaning in light of the travaux préparatoires. ${ }^{30}$ The applicants had strong reasons to argue that Article 155(2) generated an obligation for the Commission to submit a proposal at their joint request. This provision states

that the agreements concluded at Union level shall be implemented either in accordance with the procedures and practices specific to management and labour and the Member States or, in matters covered by Article 153, at the joint request of the signatory parties, by a Council decision on a proposal from the Commission.

According to the GC, the word 'shall' should be interpreted as 'may' in a literal interpretation. ${ }^{31}$ This means that words in a literal interpretation mean the opposite of what their lexical meaning entails. 'Qui potest capere, capiat. ${ }^{32}$ Astonishingly, the GC reasoning includes considerations which might be more appropriate for a historical interpretation. It refers to the fact that initially in a proposal drafted by the European social partners and submitted to the Member States, the word 'may' had been used and was subsequently and deliberately replaced by the word 'shall' ${ }^{33}$ It is hard to see how this interpretation would plead in favour of the optional character of a granting of the request

Ibid, paras 49-119.

30 Ibid, paras 49-63.

31 Ibid, para 60.

32 Matthew, XIX, 12.

33 EPSU (n 6) paras 56-7. 
addressed to the Commission. Nevertheless, the GC stated that the mandatory connotation of the word 'shall' can be explained by the fact that the drafting States would have liked to indicate that there were only two ways to implement the agreement. Arguably, this is questionable. In fact, it is hard to see why a legal provision should state that an agreement can only be implemented following either an heteronomous or an autonomous avenue. What could possibly have been a third way that needed to be excluded?

The added value of Article 155(2) can only relate to a potential role of the European institutions. In fact, social partners can ensure an autonomous avenue of implementation. They do not need any authorization from the EU to implement European agreements according to the practices of social partners and the Member States at that local level. Hence, the added value of Article 155(2) TFEU resides in the fact that the will of the people can be expressed by the representatives to whom these rules apply, namely management and labour instead of elected representatives of the European Parliament. Furthermore, the provision entails a genuine obligation for the European Commission to promote the European Social Dialogue by submitting a proposal. ${ }^{34}$

The Court also submitted Article 155(2) to what it calls a contextual interpretation. ${ }^{35}$ It can be argued that the GC deliberately chose to analyse solely those parts of the Treaties which were helpful to corroborate its decision. In particular, the Court referred to Article 17 TEU, which in no way deals with the legitimate interests of the citizens of Europe, nor with democracy and other European values. It solely deals with the institutional power of the European Commission. Essentially, the GC grounded its decision on a confrontation between an institutional actor and civil society around the issue of legislative powers and around the idea of the independence of the Commission, which should be prevented from taking instructions from any government institution, body, office or entity.

Article 17 TEU highlights the central role of the European Commission in pushing the process of European integration in an exclusive way. The rationale behind its central role is indicated in Article 17(1) TEU. The European Commission has the role of promoting the general interest of the Union by taking appropriate initiatives to that end. At first glance, Article 17(2) TEU does not contradict the thesis that a provision in an entirely different Treaty would oblige the Commission to submit a proposal for a directive implement-

34 In support of its reasoning, the GC states that the interpretation of the applicants would even amount to an obligation for the Council to adopt a directive, despite the fact that this issue was not at the heart of the annulment procedure, and despite the fact that the $\mathrm{GC}$ recognized that it was common ground for all parties that they at least agreed on the non existence of this obligation. EPSU (n 6) para 62.

35 Ibid, paras 64-82. 
ing an agreement. ${ }^{36}$ In its reasoning, the GC has simply disqualified directives implementing agreements as legislative instruments. ${ }^{37}$ This obiter dictum is probably a more major blow than the dictum finale of the judgment. In order to do so, the GC refers to Article 289 TFEU's definition of a legislative procedure. This provision was introduced by the Lisbon Treaty. The disqualification of directives implementing agreements can only be explained by the fact that the European Parliament does not participate in the process. In sum, the GC interprets Article 155(2) TFEU dating back to Maastricht in the light of an 'original' TCE provision, enshrined in another Treaty (Article 17 TEU), which it interprets in the light of a provision as recent as the Lisbon Treaty.

The GC underlined that the Commission has a margin of appreciation which is not limited to issues of legality but also involves appreciation of the appropriateness of implementation, by having regard to relevant political, economic and social considerations. ${ }^{38}$ It further highlighted that management and labour are not capable of promoting the general interest of the Union, since they would only represent a part of the multiple interests that must be taken into account. The GC, finally, observed that the interpretation given by the applicants would alter the institutional balance. ${ }^{39}$

Under the heading 'teleological interpretation', the GC focused on two key provisions in the Social Policy Title which tend to indicate an objective to be promoted. ${ }^{40}$ Whereas Article 151 TFEU indicates that dialogue between management and labour is one of the objectives to be promoted, Article 152 TFEU states that the Union (hence all European institutions, including the GC) needs to promote the roles of that dialogue's actors. The GC reduced the obligations stemming from these objectives to obligations to refrain from influencing social partners, whereas an obligation to promote should logically entail an obligation to ensure and to intervene. Although these provisions constitute what could be called the conceptual framework of the Social Policy Title, including Article 155(2) TFEU, the GC did not consider them relevant for a contextual interpretation.

In relation to other relevant provisions such as the principle of democracy, horizontal subsidiarity, the right to negotiate and conclude collective agree-

36 Indeed, this provision does provide that the principle that Union legislative acts may only be adopted on the basis of a Commission proposal, except where the Treaties provide otherwise. According to the same provision, 'Other acts shall be adopted on the basis of a Commission proposal where the Treaties so provide'. In the latter scenario, no exceptions seem to be allowed.

$37 \quad E P S U$ (n 6) para 69.

38 Ibid, para 79.

39 Ibid, para 81.

40 Ibid, para 83. 
ments and the notion of a social market economy (Article 3 TEU and Article 9 TFEU), the GC applied a rather narrow approach. In particular, democracy has been reduced to parliamentary democracy, while the horizontal dimension of the principle of subsidiarity has been ignored. In addition, the GC considered that Article 28 of the CFREU, Article 3 TEU and Article 9 TFEU do not compel the institutions to implement an agreement. Last but not least, the GC ignored the fact that the policy of the European Commission was unprecedented and at odds with numerous communications on the European Social Dialogue. ${ }^{41}$ Despite the fact that the Commission's refusal was incompatible with this longstanding tradition of communications stemming from the Commission, the GC squashed the argument on the basis of the argument that communications were not legally binding.

\subsection{How (Not) to Interpret a Constitution}

In the judgment above, the GC was essentially asked to interpret a provision of EU constitutional law. It had to rule as a constitutional Court. Constitutions of a legal order tend to consist of different sections. First, there are institutional provisions attributing power to EU institutions and those related to checks and balances. They empower institutions, rather than citizens or social partners. Second, there are provisions which tend to protect citizens against this European leviathan. European citizens had to wait half a century to obtain such a Bill of Rights in force with the same value as the Treaties. ${ }^{42}$ Last, there are provisions which indicate objectives, constituting the rationale of the machinery of power. There is no formal hierarchy between provisions of primary EU law, which gives much leeway to a constitutional Court. In such a situation, courts can do two things. They can interpret the provisions dealing with the machinery of power to the detriment of the Bill of Rights - of the values and the objectives giving legitimacy to EU institutions, in sum - to the detriment of its Social Constitution. This judicial pathway is a dangerous one. It only corroborates what even Monti has called in another context 'the potential to alienate from the Single Market and the EU a segment of public opinion, workers' movements and trade unions, which has been over time a key supporter of economic integration' ${ }^{43}$

\footnotetext{
41 Ibid, para 101.

42 The Charter of Fundamental Rights of the European Union entered into force in 2009, whereas the Treaty establishing a European Economic Community dates back to 1957.

43 Mario Monti, 'A new strategy for the single market, Report to the President of the Commission' (Report, 9 May 2010) 68, at https://images.irpa.eu/wp-content/ uploads/2019/04/monti_report_final_10_05_2010_en.pdf accessed 19 June 2021.
} 
There is little doubt that the judgment of the GC is of no help to the promotion of the right to collective bargaining as enshrined in Article 28 CFREU. Article 51 CFREU makes it abundantly clear that the Charter rights need to be promoted by all EU institutions. The same messages prevail in Articles 151 and 152 TFEU. The judgment neither promotes the European social partners nor does justice to the right to collective bargaining. It actually undermines the social dimension of the European Union outside any purview of promoting the so-called fundamental economic freedoms. It is deprived of any balancing. Although it cannot be considered as an example of negative integration, it does essentially create an obstacle to the development of positive integration.

The reference made by the GC to Article 17 TEU, which is at the core of the reasoning, is a clear-cut illustration of the will of the GC to put the machinery of power at the core of the Treaties. ${ }^{44}$ It is slightly ironic that this provision is being perverted in order to justify the refusal of the Commission to take an appropriate initiative, whereas this provision has been phrased to push the European Commission to adopt initiatives. ${ }^{45}$ By giving so much weight to a TEU provision in order to deprive a TFEU provision of its substance, the GC neglects the fact that both treaties have the same value. The judgment thus violates a basic principle of interpretation: Specialia derogant generalibus. Article 155 (2) TFEU is clearly the most specific provision. It has the power for that reason even to derogate from the CJEU's troublesome interpretation of Article 17 TEU.

\subsection{The Ignored Role of the European Social Dialogue in Enhancing the Legitimacy of the European Commission and in Restoring Institutional Balances}

As discussed above, the GC has stated, in a remarkable dictum, that the reasoning of the applicants would alter the institutional balance to the detriment of the European Commission. ${ }^{46}$ Arguably, this constitutes a myopic view on the role of social partners in the development of social policy. Rather than stating that the applicants' intervention in the European Social Dialogue would alter the institutional balance to the detriment of the Commission, the Court should have put an end to this falsification of history. The European Social Dialogue has been invented by the European Commission in order to enhance its legitimacy and restore an institutional balance enabling it to push the process of

$44 \quad E P S U$ (n 6) paras 65-7.

45 Article 17 TEU states: 'The Commission shall promote the general interest of the Union and take appropriate initiatives to that end' (emphasis added).

46 EPSU (n 6) para 81. 
European integration. This mechanism has been called the Moment Delors. ${ }^{47}$ Its invention has helped to empower both the trade unions and the European Commission in a dynamic which the late Brian Bercusson accurately described as bargaining under the shadow of the law. ${ }^{48}$ The 'risk' of a legislative intervention by the Commission helped to convince the employers' association to start a bargaining process. On the other hand, the fact that a proposal was based upon a previous agreement concluded by management and labour helped the Commission convince the Council to adopt its proposal.

This mechanism presupposes that the Commission is open to a progressive development of labour standards. In other words, the Commission cannot just use the social partners when it wishes to push integration and ignore them when it wants to push an alternative agenda of so-called Better Regulation. If the Commission is only willing to push the kind of agreements supported by management and labour that are of its own liking, and in practice even urges the renegotiation of agreements until the Commission likes the result, the institutional balance will indeed be altered, but this time to the detriment of the social partners. There is a serious risk that the Social Dialogue will not take place under the shadow of 'the law', however imprecise and unpredictable, but rather under the negative shadow of the European Commission. This transformation would mean a mancipation instead of an emancipation of the social partners, and a threat to their autonomy.

\section{THE EUROPEAN SOCIAL DIALOGUE, PERHAPS NOT BARGAINING, BUT DEFINITELY AN ISSUE OF LEGISLATION}

The idea that directives would not constitute legislation is at odds with the historiography on the emergence of the European Social Dialogue and of its institutionalization prior to the conclusion of the respective agreements. ${ }^{49}$ In his seminal doctoral thesis, Lo Faro questioned whether agreements concluded within the framework of the European Social Dialogue could actually be

\footnotetext{
$47 \quad$ See Didry and Mias (n 4) 349.

48 Bercusson (n 21) 538-9.

49 See especially: Jean Degimbe, La politique sociale européenne. Du traité de Rome au traité d'Amsterdam (ETUI 1999) 260; and Didry and Mias (n 4) 349; Jon-Erik Dolvik, An Emerging Island? ETUC, Social Dialogue and the Europeanisation of the Trade Unions in the 1990s (ETUI 1999) 249; and Daniel Dumont, 'Le dialogue social européen et ses instruments : du soft au hard law, et retour' in Isabelle Hachez et al (eds), Les sources du droit revisitées - Collection (Anthemis 2013).
} 
interpreted as a genuine expression of collective autonomy at EU level. ${ }^{50} \mathrm{He}$ considered this an instrumentalization of social partners to overcome a legislative deadlock. The fact that the negotiation of social partners was functional to a legislative process convinced him that collective autonomy at EU level was fictitious. The position of the GC reverses this analysis in a Copernican way. It suggests that EU directives implementing these agreements are not genuine legislation.

My claim is that the idea that EU directives implementing these agreements would not constitute legislation in the meaning of Article 17 TEU is bizarre. The reasoning of the GC is essentially based upon a Treaty provision which only came into force in 2009, whereas nearly all of the directives implementing agreements were adopted prior to the entry into force of the Lisbon Treaty. The idea that directives implementing agreements prior to 2009 would cease to constitute 'legislative' acts was simply unheard of prior to the EPSU judgment. In fact, the GC makes use of a provision which is much more recent than the implemented agreements to make that point. These directives have all been implemented after a process of induced bargaining. Thus, the Commission was already consulting the social partners, because it envisaged legislative interventions through a proposal of a directive. It is extremely bizarre that if a successful bargaining process resulted in a joint request for implementation, the subsequent directive would not constitute legislation.

In the Chatzi case - which is not sufficiently taken into account, despite dealing with the European Social Dialogue - the CJEU made it abundantly clear that it will interpret a directive implementing a collective agreement concluded at European level just like any other (legislative) directive:

The Court, for its part, derives its jurisdiction to interpret directives from Article 267 TFEU. The Framework Agreement is admittedly the product of a dialogue, based on the Agreement on Social Policy, between management and labour at European level, but it has been implemented, in accordance with Article 4(2) of the Agreement on Social Policy, by a Council directive, of which it is thus an integral component (see, to this effect, Case C-537/07 Gómez-Limón Sánchez-Camacho [2009] ECR I-6525, paragraph 34). [...] It follows that the jurisdiction of the Court to interpret the Framework Agreement does not differ from its general jurisdiction to interpret other provisions contained in directives. ${ }^{51}$

50 Lo Faro (n 5) 192. The Italian title of the $\mathrm{PhD}$ thesis is clearer and more poetic: Funzioni et Finzioni della Contrattazione collettiva communitarian - the European Social Dialogue is fictitious bargaining and is ancillary to a legislative process, despite the rhetoric of the provisions of the TFEU. Hence, it is not the intervention of the Council which is ancillary to the European Social Dialogue.

51 Case C-149/10 Zoi Chatzi v Ypourgos Oikonomikon ECLI:EU:C:2010:534, paras 24-5. 


\title{
6. THE EUROPEAN SOCIAL DIALOGUE, A PART OF THE 'DEMOCRATIC LIFE OF THE UNION'
}

As suggested in section 4.1, the GC has set out a very narrow understanding of the notion of democracy. It essentially reduces the democratic process as an issue of parliamentary participation. According to the Court, the view of the applicants would actually amount to an undemocratic solution whereby the Commission would be prevented from following an ordinary legislative avenue after the conclusion of an agreement and a subsequent joint request. ${ }^{52}$ In order to construe the quintessential involvement of the Parliament, the GC furthermore invokes the Ueapme judgment. It is true that the Court of First Instance (CFI) stated in Ueapme that 'the participation of that institution (EP) in the Community legislative process reflects at Community level the fundamental democratic principle that the people must share in the exercise of power through a representative assembly'. ${ }^{53}$ However, the way in which the GC presents the reasoning developed in Ueapme is selective and misleading, if not fallacious. It completely disregards that the CFI clearly indicated in the subsequent paragraph of Ueapme that the sufficiently representative status of the social partners drafting the agreement is a valid and legitimate substitute for that parliamentary participation:

\begin{abstract}
However, the principle of democracy on which the Union is founded requires - in the absence of the participation of the European Parliament in the legislative process - that the participation of the people be otherwise assured, in this instance through the parties representative of management and labour who concluded the agreement which is endowed by the Council, acting on a qualified majority, on a proposal from the Commission, with a legislative foundation at Community level. In order to make sure that that requirement is complied with, the Commission and the Council are under a duty to verify that the signatories to the agreement are truly representative. ${ }^{54}$
\end{abstract}

The GC's suggestion that the Commission could completely ignore the expression of the will of the people as represented by management and labour on issues which directly affect in casu their interests, by submitting a proposal according to the ordinary legislative avenue, is irresponsible. Not only does it undermine the constitutional role of the European Social Dialogue in the field of social policy and the repeated pledge of the Commission to implement ne varietur; it also poses a serious threat to the legitimacy of both social partners and the European Parliament. This would actually go against the expression

\footnotetext{
$52 \quad E P S U$ (n 6) paras 95-6.

53 Case T-135/96 Union Européenne de l'artisanat et des petites et moyennes entreprises (UEAPME) v Council of the European Union ECLI:EU:T:1998:128, para 88.

54 Ibid, para 89.
} 
of the will of the people. Democracy is about the right of the people to govern themselves as well. ${ }^{55}$ In the EPSU case, the substance of the agreement is the organization of industrial relations between the employers and the employees, duly represented by the representative signatory parties. As the CJEU indicated itself in UGT FSP, autonomy means the right of self-government or, more accurately, in French 'le droit de se gouverner par ses propres lois'. ${ }^{56}$ Therefore, democracy and collective autonomy can go hand in hand as long as the 'demos', or else the 'people', concerned are identified. In the case of the agreement at hand, the demos concerned with the information and consultation procedure is the persons who have a right to be informed and consulted. That demos is more adequately represented by the social partners concerned than by elected parliamentarians.

In light of the above, the idea that the role of social partners could be a threat to democracy boils down to a nineteenth-century and parliamentary vision of democracy flavoured by disregard for the civil society and its intermediaries. The judgment will not be helpful to construe the European Union in a more bottom-up fashion. In the now abandoned Constitutional Treaty on the European Union, the crucial contribution of the autonomous Social Dialogue to the democratic life of the Union was expressed a monte by distinguishing it from representative and parliamentary democracy. ${ }^{57}$

\section{THE EUROPEAN SOCIAL DIALOGUE AND HORIZONTAL SUBSIDIARITY: A MEANS TO PROTECT CITIZENS}

The ability to recognize the European Social Dialogue as an aspect of democracy is intertwined with a vision of horizontal subsidiarity. Horizontal subsidiarity is much older than vertical subsidiarity. It relates to the relationship between institutional actors and social partners within the same geographical borders, whereas vertical subsidiarity relates to a relationship between institutional actors active within divergent borders. ${ }^{58}$ As discussed earlier, the GC has ignored the existence of horizontal subsidiarity. This can be considered as

\footnotetext{
55 This statement is based upon the etymological analysis of the word 'demo-cracy'.

56 Case C-151/09 Federación de Servicios Públicos de la UGT (UGT-FSP) mot Ayuntamiento de La Linea de la Concepción, María del Rosario Vecino Uribe och Ministerio Fiscal ECLI:EU:C:2010:452, para 42.

57 See Article I-48 Treaty establishing a Constitution for Europe.

58 See Filip Dorssemont, 'Contractual Government by Management and Labour in EC Law' in Aukje Van Hoek et al (eds), Multilevel Governance in Enforcement and Adjudication (Intersentia 2006) 285.
} 
another example of historical amnesia. ${ }^{59}$ Horizontal subsidiarity can in fact be traced back to at least Quadragesimo Anno, where the Pope exercised a (too) subtle critique of the way the so-called leggi fascistissime undermined the autonomy of industrial relations. ${ }^{60}$

Horizontal subsidiarity as enshrined in Article 155(2) has, in essence, a procedural dimension. This is that the Commission is forced to consult management and labour if it envisages an action in the field of social policy. The question whether it is more appropriate for the Commission to act on its own rather than leaving an issue up to the social partners should not even be raised, as an action of the Commission without prior consultation is per se unconstitutional. In other words, this is not an issue of appropriateness, but one of legality. In the same vein, it is argued that the Commission has an obligation to submit a proposal, provided that relevant legality checks have been conducted.

A similar example of horizontal subsidiarity can be found in the wording of a number of directives, more particularly in the field of worker involvement. For example, in the EWC Directive 94/45 and the Recast EWC Directive 2009/38, the notion of subsidiary requirements has been used. These requirements apply if a so-called special negotiating body has been unsuccessful in concluding an agreement with the central management. The statutory solution has a subsidiary character. This model has been a kiss of life for the introduction of the European company. Both the Societas Europaea Directive 2001/86 and the Societas Cooperativa Europaea Directive 2003/72 copy this model. ${ }^{61}$ Thus, the GC missed an opportunity to recognize a general principle of subsidiarity of which Article 5 TEU might be the vertical expression.

\section{THE AGREEMENT AS A MEANS TO ENHANCE EQUALITY AND A CONTRIBUTION TO A UNIVERSAL LABOUR GUARANTEE}

Democracy is also related to an idea of equality of citizens in relation to participation. It is questionable that a parliamentary system which deprives citizens

59 The first amnesia relates to the fact that the whole idea of the European Social Dialogue was a way to overcome a legislative deadlock. See also the quote from Marc Bloc which Jan-Paul Tricart used above the introduction of his study Legislative implementation of European social partners agreements: challenges and debates, ETUI Working paper 2019/09: 'Ignorance of the past not only confuses contemporary science but confounds contemporary action.'

60 See inter alia: Deborah Z. Cass, 'The Word that Saves Maastricht? The Principle of Subsidiarity and the Division of Powers within the European Community' (1992) 29(6) Common Market Law Review 1110 and Vlad Constantinesco, 'Who Is Afraid of Subsidiarity?' (1991) 11 Yearbook of European Law 33, 34-5.

${ }_{61}$ See Dorssemont (n 58) 285-312. 
of the right to vote on the basis of their status or sex could qualify as democracy. Contemporary parliamentary democracies are also based upon the principle of one (hu)man, one vote. These observations seem self-evident, but it took more than a century from the foundation of the Belgian state (1830-1) to reach that point (1948). The CGA Agreement has been construed as an attempt to widen mechanisms of worker involvement enshrined in EU directives to involve a category of workers which has been systematically excluded from these mechanisms: citizens working for central governmental administrations. However, as indicated above, the Commission used what seems to be a legal argument, namely equality, to indicate that it cannot intervene.

The Commission contended that the notion of central governmental administration is not an autonomous concept of EU law and, as a result, the scope of the expected directive could not ensure full equality. In my view, this argument is astonishing. It is quite common in the field of EU directives that some of them do not enshrine an autonomous concept of the employee, in which case the notion of employee needs to be defined by means of a renvoi to the law of the Member States. This has never been an obstacle, let alone a legal impediment, to the European Union's adoption of a directive. For example, the European Union has overcome the exclusion of seafarers through a legislative intervention in the name of equality. In Directive (EU) 2015/1794 (4th and 5th recitals), it is stated:

The existence of, and/or possibility of introducing, exclusions may prevent seafarers from fully enjoying their rights to fair and just working conditions and to information and consultation, or limit the full enjoyment of those rights. Insofar as the existence of, and/or possibility of introducing, exclusions is not justified on objective grounds and seafarers are not treated equally, provisions which allow such exclusions should be deleted.

The present legal situation, existing in part as a result of the specific nature of the seafaring profession, gives rise to unequal treatment of the same category of workers by different Member States, according to whether or not they apply the exclusions and optional exclusions allowed by the legislation in force. A significant number of the Member States have made no, or only limited, use of those optional exclusions.

It is worth adding that this directive has not introduced a uniform or autonomous concept of a seafarer.

\section{CONCLUSION}

Based on the analysis above, the judgment of the GC is a twisted one. The impact of the judgment on the European Social Dialogue and the future of EU social policy depends on an appeal procedure pending before the Court of Justice. If the GC judgment is not quashed, two positive outcomes can already 
be discerned. ${ }^{62}$ First, the signatory parties have legal standing to attack a refusal by the Commission to implement their agreements. Second, the refusals will need to be duly motivated. The GC has missed an excellent opportunity to do justice to the principles of democracy and subsidiarity and to uphold a duty to promote social dialogue and the autonomy of the social partners. It has also missed the chance to bridge a discriminatory gap between private employees enjoying a right to information and consultation and workers in central governmental administrations to which the EU directives tend to lend a blind eye.

The GC was keen to reduce democracy to parliamentary democracy, failing to recognize that the involvement of social partners can enhance the democratic life of the European Union. In the same vein, it reduced the subsidiarity debate to one of public law actors, in disrespect of the more horizontal dimension of that principle. The argument of equality has not convinced the General Court. As a result of this refusal, State actors in their relations to its staff can continue to ignore what these States have to impose upon private employers in their relation to their workers. This vision takes us back to a Jacobine conception which prevailed during the French Revolution but which is unfit for the twenty-first century, and likely to generate painful contradictions.

The refusal of the European Commission to submit a proposal has had a chilling effect on the trustworthiness of the European Social Model. Where the Commission has used the Social Dialogue in an era of legislative deadlock organized by the Council, it has now betrayed their trust in an era where it is organizing this deadlock on the altar of Better Regulation.

The ESD cannot function outside the shadow of the law. Neither can negotiations a fortiori take place under the dark and negative shadow of the European Commission. The refusal of the Commission to submit a proposal is all the more problematic in light of the uncertain status of agreements which are not implemented at all. Whereas governmental intervention in the Member States seeks to extend the legal bindingness of the collective agreement, in this scenario the implementation is a prerequisite for the legal bindingness of the collective agreement.

62 After the closure of the drafting of this contribution, Advocate General Pikamae delivered an opinion which endorses the outcome and the reasoning of the General Court: see Opinion of 20 January 2021 in Case C-928/19 P; a CJEU judgment on 2 September 2021 dismissed the appeal (ECLI:EU:C:2021:656). 